\title{
'Suffering Violence' and the kingdom of heaven (Mt 11:12): A Matthean manual for life in a time of war
}

\begin{abstract}
Author:
Dorothy Jean Weaver ${ }^{1,2}$

Affiliations:

${ }^{1}$ Eastern Mennonite

Seminary, United States

${ }^{2}$ Department of New

Testament Studies,

University of Pretoria,

South Africa

Note:

Prof. Dr Dorothy Jean

Weaver is a research

associate of Prof. Dr

Andries G. van Aarde,

Department of New

Testament Studies, Faculty

of Theology, University of

Pretoria, South Africa. In

honour of the prodigious

efforts Andries van Aarde

has put out on behalf of

Matthean studies over past

years.
\end{abstract}

Correspondence to:

Dorothy Jean Weaver

email:

weaverdj@emu.edu

Postal address:

Eastern Mennonite

Seminary, 1200 Park Road,

Harrisonburg, VA, 22802-

2462, United States

Dates:

Received: 06 Dec.2010

Accepted: 02 Feb. 2011

Published: 07 June 2011

How to cite this article:

Weaver, D.J., 2011

"Suffering Violence" and the kingdom of heaven ( $\mathrm{Mt}$

11:12): A Matthean manual for life in a time of war',

HTS Teologiese Studies/

Theological Studies 67(1),

Art. \#1011, 12 pages. DOI:

10.4102/hts.v67i1.1011

(C) 2011. The Authors. Licensee: OpenJournals Publishing. This work is licensed under the Creative Commons Attribution License.
Matthew's Gospel has much to say about 'suffering violence'. As Jesus comments (11:12, NRSV), 'From the days of John the Baptist until now the kingdom of heaven has suffered violence, and the violent take it by force'. Through his narrative rhetoric Matthew offers multi-layered perspectives on life lived vis-à-vis ongoing violence. These perspectives reflect (1) the experiences of the righteous as they encounter violence, (2) the words of Jesus depicting or predicting the sufferings of himself and others, (3) the words of Jesus calling people to faithful responses to violence, and (4) Matthew's own narrative rhetoric offering theological reflection on the suffering of the righteous. This study examines the Matthean theme of 'suffering violence'; the first section focuses on the nature and cause of the violence faced by the righteous; the second section focuses both on Jesus' call to faithful responses to violence and on actual lived responses to violence; the final section focuses on the rhetorical strategy of Matthew's narrative in relation to the question of violence and assesses Matthew's theological reflections on the suffering of the righteous. The study concludes with brief reflections on the present-day implications of Matthew's text for life 'in a time of war'.

\section{Introduction}

The time was November 2000. The place was Bethlehem. I was on assignment at the International Center of Bethlehem (ICB) at Christmas Lutheran Church, teaching a course on the life of Jesus for Palestinian tour guiding students. But the circumstances were grim. The outbreak of violence now known as the Second Intifada had begun only weeks before, at the end of September. Fierce gun battles between Palestinian gunmen hiding behind olive trees in the Palestinian town of Beit Jala and Israeli soldiers stationed across the valley in the Israeli settlement of Gilo shattered the quiet of Bethlehem evenings on a regular basis. And the loud booms of exploding shells and the menacing drone of helicopter gunships with their terrifying bursts of machine gun fire called me frequently from my bed to the window for anxious nighttime vigils in which the only prayer I could muster was, 'O God, no!'

And then one day in our staff meeting at the International Center, Rev. Dr Mitri Raheb invited me to write an Advent meditation for the online newsletter of the ICB. I accepted his invitation. As soon as I did, I knew exactly what I needed to write. There was no question and no hesitation. I was living in Bethlehem in a time of war. I knew that the text for the moment was Matthew 2:1-23, Matthew's account of a similar time of military violence and unspeakable horror in Bethlehem. Within a few short hours 'Bethlehem: An Advent Meditation'1 virtually wrote itself (Weaver 2001:54). The task of 'Reading Matthew in a Time of War', far from being an academic exercise, became instead the urgent task of reaching out to Matthew's narrative for a profound word of hope in the midst of present chaos and violence.

Matthew, the Gospel Writer, has much to say about 'suffering violence'. As Jesus comments to his listeners in reflecting on the ministry of John the Baptist (11:12), 'From the days of John the Baptist until now the kingdom of heaven has suffered violence (biazetai), and the violent (biastai) take it by force'. ${ }^{2}$ Jesus' words are surely true. But the truth they express extends well beyond the temporal framework delineated by 'the days of John the Baptist' on the one hand and the 'now' of Jesus' own ministry on the other. In fact the 'violence' portrayed in Matthew's Gospel reaches all the way from 'the blood of righteous Abel' (23:35) to the 'great suffering' that precedes the end of the age and the coming of the Son of Man $(24: 21,29)$. As Matthew sees it, 'suffering violence' is a given fact of life for God's righteous ones throughout history:

- $\quad$ Abel (23:35)

- Zechariah, son of Barachiah (23:35), the prophets $(5: 12 ; 23: 37)$, and those 'sent' to Jerusalem $(21: 34-36 ; 23: 37)$

1.This essay was later published as 'The massacre of the innocents', in R. O'Grady (ed.), 2001, Christ for all people: Celebrating a world of Christian art, p. 54, Orbis Books, Maryknoll, NY.

2.All biblical citations in this article are taken from the New Revised Standard Version unless otherwise designated. 
- Joseph with 'the child and his mother' (2:13-15, 19-23)

- the mothers and infants of Bethlehem portrayed as 'Rachel' and her 'children' (2:16-18)

- John the Baptist ${ }^{3}$

- Jesus $^{4}$

- Jesus' disciples 5 .

Through the narrative rhetoric of his Gospel Matthew offers multi-layered perspectives to his readers on life lived in the face of ongoing violence. These perspectives reflect the lived experiences of the righteous ones in Matthew's narrative as they encounter and respond to violence, the words of Jesus depicting or predicting the sufferings of himself and others, the words of Jesus calling people to faithful responses to the violence they encounter, and Matthew's own narrative rhetoric offering theological reflection on the suffering of the righteous.

This study examines, in a threefold summary overview, the Matthean theme of 'suffering violence':

- the first section of the article focuses on the nature and cause of the violence faced by the righteous ones within Matthew's narrative

- the second section of the article focuses both on Jesus' call to faithful responses to violence and on actual lived responses to violence as reflected within Matthew's narrative

- the final section of the article focuses on the rhetorical strategy of Matthew's narrative vis-à-vis the question of violence and assesses Matthew's theological reflections on the suffering of the righteous.

The study concludes with brief reflections on the present-day implications of Matthew's text for living 'in a time of war'.

\section{The nature and cause of violence faced by the righteous}

To read the Gospel of Matthew with the question of 'suffering violence' in focus is to discover a broad stream flowing through the heart of the Matthean landscape, a stream that intersects prominently with the lives of the righteous within Matthew's narrative and shapes their experiences profoundly. As Matthew sees it, 'suffering violence' is a fundamental characteristic of the life and calling of those who are righteous. ${ }^{6}$ Accordingly, from the outset of his narrative to its conclusion Matthew paints a vivid and unrelenting portrait of the violence inflicted on and suffered by these

3.Thus 4:12; 11:2-19; 14:1-12; 17:9-13.

4.Thus $12: 14 ; 16: 21-23 ; 17: 22-23 ; 20: 17-19,22-23,28 ; 26: 1-28: 20$

5.Thus 5:10-12, 38-42, 43-48; 10:16-39; 16:24-26; 20:20-28; 22:1-14; 23:29-39; 24:1-31.

6.Thus, for example, Jesus' words in commissioning his disciples for ministry: 'See, I am sending you out like sheep into the midst of wolves'. The very character of the disciples' mission, as Jesus portrays it, is shaped from its inception by the violent response that the missioners will receive from those to whom they go. See Dorothy response that the missioners will receive from those to whom they go. See Dorothy
Jean Weaver, Matthew's Missionary Discourse: A Literary Critical Analysis (Sheffield Jean Weaver, Matthew's Missionary Discourse: A Literary Critical Analysis (Sheffield
Academic Press, Sheffield, 1990), p. 92. In this respect Jesus' disciples share the Academic Press, Sheffield, 1990), p. 92. In this respect Jesus' disciples share the
calling not only of the prophets who preceded them in suffering 'persecution' calling not only of the prophets who preceded them in suffering 'persecution' cf. 17:12) on behalf of the kingdom of heaven, and of Jesus himself, whose very cf. 17:12) on behalf of the kingdom of heaven, and of Jesus himself, whose very
mission means that he 'must ... undergo great suffering' (dei ... polla pathein: 16:21; mission means that he 'must ... unde
cf. 17:12, 22-23; 20:17-19; 26:1-2). righteous ones. This violence ranges from the personal attacks of one individual against another ${ }^{7}$ to the official and unofficial punishments meted out by authorities of the religious community or of the empire ${ }^{8}$ to the widespread devastation of wars carried out by powerful military forces $(24: 6,7)$. And the vocabulary depicting this violence ranges from general and/or metaphorical to concrete and very specific.

Speaking in broad and general terms Jesus refers to the 'persecution' [dioko, diogmos] that the prophets have encountered in the past (5:12) and that which the disciples will encounter in similar fashion in the future. ${ }^{9}$ Synonymously Jesus speaks of 'trouble', 'torture', or 'suffering' [thlipsis] that awaits his disciples whether in the present era (13:21) or in the eschatological future $(24: 9,21,29)$. In metaphorical language Jesus tells of the bridegroom that will be 'taken away' (apairo: 9:15), the cup that he must 'drink' (pino: 20:22, 23; 26:39, 42), the life that he will 'give' (didomi: 20:28), and his blood that will be 'poured out' (ekchunno: 26:28). And Jesus warns his disciples of their status as 'sheep [in] the midst of wolves' (10:16; DJW) and of the 'cup' that they too must 'drink' (pino: 20:22-23).

At the personal level, individual versus individual, violence of various sorts - emotional, verbal, legal, and physical affects the righteous ones of Matthew's Gospel. In the realm of emotions Jesus speaks of 'enemies ${ }^{\prime 10}$ and those who 'hate ${ }^{\prime 11}$ the disciples. And he warns of the 'sword' (machaira: 10:34) that will 'divide' (dichazo: 10:35; DJW) family members from each other: 'a man against his father, and a daughter against her mother, and a daughter-in-law against her mother-in-law' (10:35//Mic. 7:6). In the verbal realm people 'revile' Jesus and his disciples, ${ }^{12}$ 'utter all kinds of evil' against them, ${ }^{13}$ and 'call [them] Beelzebul'. ${ }^{14}$ On the legal front Jesus speaks of the 'evildoer' [poneros] who wants to 'sue' you [krino] and 'take' [lambano] your outer garment $(5: 38,40)$; he warns $(5: 25)$ of the 'accuser' [antidikos] who will take you 'to court'15 and 'hand you over' [paradidomi] to the 'judge' [krites]. In the realm of physical violence Jesus speaks (5:38-39) of the 'evildoer' [poneros] who 'strikes you (rhapizo) on the right cheek'; and he refers to the lex talionis, the law of retaliation invoked when one individual attacks another and gouges out their 'eye' or knocks out their 'tooth' (5:38). ${ }^{16}$ And well beyond

7.Thus 5:25, 38, 39; 10:21-22

8.Thus $2: 16 ; 5: 12 ; 10: 17-18 ; 14: 10 ; 26: 67 ; 27: 27-31,35$.

9.Thus $5: 10,11,44 ; 10: 23 ; 13: 21 ; 23: 34$.

10.echthros: 5:43, 44; 10:36//Micah 7:6.

11.miseo: 10:22; 24:9, 10; cf. 5:43.

12.oneidizo: $5: 11 ; 27: 44$.

13.lego pan poneron: $5: 11 ;$ cf. $26: 62 ; 27: 13$

14.epikaleo ... Beelzeboul: 10:25; DJW.

15.The words 'to court' are not found in the Greek original, but are clearly implied by the context.

16.The punishment for such an offense ('an eye for an eye and a tooth for a tooth': $5: 38)$ is, however, not an act of personal revenge but rather a corporate punishment carried out officially by the wider community (thus Dt 19:15-21). On the communal character of this punishment see Dorothy Jean Weaver, 'Transforming Nonresistance: From Lex Talionis to "Do Not Resist the Evil One"', in W.M. Swartley Nonresistance: From Lex Talionis to "Do Not Resist the Evil One", in W.M. Swartley
(ed.), The Love of Enemy and Nonretaliation in the New Testament, (Westminster/ (ed.), The Love of Enemy and Nonreta
John Knox, Louisville, KY), pp. 37-47. 
the level of 'eye' and 'tooth' physical violence, even amongst the most intimate of relations, is often deadly. Jesus points back through Jewish history to the 'blood of righteous Abel' (23:35), a man murdered by his brother (Gn 4:8-11); looking towards the future he warns of a time to come when 'brother will [hand over (paradidomi] brother to death, and a father his child, and children will rise up (epanistamai) against parents and have them put to death (thanatoo)' (10:21; DJW). ${ }^{17}$

But whilst violence of all types at the personal level is clearly a fact of life for the righteous ones in Matthew's narrative, the predominant depiction of violence is of that which happens at the judicial level. Here official or unofficial punishment is meted out by the authorities of the religious community or of the empire in accordance (or not!) with legal statutes governing such actions. These acts of violence as portrayed in Matthew's narrative fall into a handful of broad categories:

- conspiracy

- $\quad$ arrest and imprisonment

- court trials and verbal abuse

- physical abuse and torture

- execution and/or murder.

Cynical and clearly extra-judicial acts of conspiracy lie behind much of the judicial violence depicted in Matthew's narrative. Herod, the Jewish client king ruling Judea at the time of Jesus' birth, engages in conspiratorial actions (2:7-8) designed to 'destroy' (apollymi: 2:13) his rival, the 'child who has been born king of the Jews' (2:2). The wicked tenants of Jesus' parable (21:33-46) take similar conspiratorial steps to 'seize' (lambano: 21:39) and 'kill' (apokteino: 21:38, 39) the son of the vineyard owner. The religious leaders - Pharisees, chief priests, and elders of the people - then fulfill the words of Jesus' parable by 'conspiring' or 'devising plans' against Jesus $^{18}$ to 'arrest' him (krateo: 26:4), 'kill' him (apokteino: 26:4), and 'destroy' him (apollymi: 12:14). Characteristics of these conspiracies are 'secrecy' (lathra: 2:7) and 'stealth' (dolos: 26:4), bribery (26:14-16) and 'blood money' (time haimatos: 27:6: cf. 27:3-4), 'jealousy' (phthonos: 27:18), and the political clout necessary to 'persuade' the masses (peitho: 27:20), cause public 'riots' (thorybos: 27:24; cf. 27:23), and force the hand of the Roman governor (27:24). ${ }^{19}$

The correlated acts of arrest and imprisonment begin the formal process of judicial violence as Matthew portrays it. The predominant technical term for this process is that of 'handing over' [paradidomi], a term widely used to depict the arrests of John the Baptist (4:12), Jesus, ${ }^{20}$ and Jesus' disciples. ${ }^{21}$ A roughly similar sequence of events is depicted for such

17.The family members of 10:21 are not depicted as murderers who kill with their own hands but rather as those who 'hand over' their next of kin for execution by the powers that be.

18.symboulion lambano: $12: 14$; 27:1; symbouleuo: $26: 4$

19.Cf. 2 Chronicles 24:20-21, which depicts the people of Judah 'conspiring' against Zechariah, an act which leads to his stoning death in the temple court. See also Matthew's depiction of the 'resurrection conspiracies' devised by the Jewish leaders first to ensure that Jesus' body stays in the tomb (27:62-66) and then to leaders first to ensure that Jesus' body stays in the tomb ('

20.Thus 10:4; 17:22; 20:18, 19; 26:2, 15, 16, 21, 23, 25, 45, 48; 27:2, 3, 4, 18, 26.

21.Thus $5: 25 ; 10: 17,19,21 ; 24: 10$. arrests. Jesus warns his disciples (5:25) of the 'accuser' [antidikos] who hands a person over to the 'judge' [krites], who in turn hands them over to the 'guard' [hyperetes]. Elsewhere the arrest is instigated by a ruler (presumably acting by proxy; $14: 3$ ) or by a crowd - on occasion armed with 'swords and clubs' (machairon kai xylon: 26:47,55) as one would do to arrest a bandit (26:55) - who 'lay hands' on someone (epiballo tas cheiras: 26:50), 'seize' them,'22 and 'bind' them (deo: 14:3; 27:2). Then the 'prisoner' (desmios: 27:15, 16) is 'led away' (apago: 26:57; 27:2, 31), 'dragged' before the ruling authorities (ago: 10:18), ${ }^{23}$ and 'handed over' to them (paradidomi: 27:2). Typically the prisoner is then 'put' (apotithemi: 14:3) or 'thrown' (ballo: 5:25) into 'prison'. ${ }^{24}$

Beyond the violence of arrest and imprisonment the righteous ones of Matthew's narrative also encounter the judicial (and extra-judicial!) violence connected with court proceedings. They experience verbal abuse both within and beyond the courtroom. At the house of Caiaphas the religious leaders seek 'false testimony' (pseudomartyria: 26:59) against Jesus and call forward 'false witnesses' (pseudomartys: 26:60) to tell lies about him. Before Pilate they 'accuse' Jesus (kategoreo: 27:12; cf. 12:10) and 'make accusations against' him (katamartyreo: 27:13). For his part Caiaphas the high priest charges Jesus with 'blasphemy' (blasphemeo: 26:65), whilst the passersby at Golgotha 'blaspheme' Jesus themselves (blasphemeo: 27:39; NRSV footnote) and call on him to 'save himself' (27:40). Before Caiaphas the religious authorities ridicule Jesus' apparent powers as 'Messiah' and demand that he 'prophesy' to them (27:68), whilst the Roman soldiers at the governor's headquarters 'mock' Jesus verbally [empaizo] as they kneel before him and acclaim him 'King of the Jews' (27:29, 31; cf. 20:19). After the crucifixion the chief priests, scribes, and elders likewise 'mock' Jesus verbally (empaizo: 27:41), deriding his apparent inability to 'save himself', taunting him to 'come down from the cross', and calling on God to 'deliver him now, if he wants to' (27:42-43). Nor does the verbal abuse end when Jesus dies. Following Jesus' death these same religious authorities pronounce Jesus a 'deceiver' (planos: 27:63). And they refer to the potential story of his resurrection as the 'last deception' [eschate plane] which would be 'worse than the first' (27:64), presumably that 'deception' carried out by the life and ministry of Jesus 'the deceiver'.

The litany of physical abuses suffered by the righteous ones of Matthew's narrative at the hands of Jewish or Roman authorities is lengthy; and the punishments range from insult and humiliation to torture and brutality. Insult and humiliation are reflected in such actions as 'spitting' in someone's face (emptyo: 26:67; 27:30), 'shaking one's head' at another person (kineo: 27:39), 'gathering' a large crowd around someone in order to mock them (synago: 27:27), publicly stripping a person of their clothing (ekdyo: 27:28, 31),

22.krateo: 14:3; 21:46; 22:6; 26:4, 48, 50, 55, 57; lambano: 21:35, 39; cf. 21:36.

23. Here the disciples appear before unnamed 'governors and kings'. Jesus, for his part, appears first before Caiaphas the high priest and the scribes and elders gathered at his house (26:57) and then before Pilate the governor (27:2).

24. phylake: 5:25; 14:3, 10; desmoterion: 11:2. 
publicly dressing them in other clothing (peritithemi: 27:28; endyo: 27:31), 'putting' things on the head or in the hand of another (epitithemi: 27:29), 'kneeling' before them in mock homage (gonypeteo: 27:29), and 'dividing' someone's clothing after their execution (diamerizo: 27:35) through the casual game of 'casting lots' (ballo kleron: 27:35). A well-known and no doubt especially galling method of humiliation within the occupied Palestine of Matthew's story was for a Roman soldier to 'force' or 'compel' a Jewish civilian to carry a burden - in some cases a heavy wooden cross - for the distance of one mile (angareuo: 5:41; 27:32).

But the physical abuse suffered by the righteous in Matthew's narrative moves far beyond humiliation and insult. Torture and brutality are reflected in such acts as the Jewish communal practice of exacting 'an eye for an eye and a tooth for a tooth' from the one who has assaulted another (5:38; cf. Dt 19:15-21) $)^{25}$ and the ugly Roman game of twisting thorns into a sharp and painful 'crown' to 'put' (epitithemi: 27:29) onto the head of a prisoner. The list of official brutalities goes on. The righteous ones are 'mistreated' (hybrizo: 22:6), 'struck' with the hand (kolaphizo: 26:67) or with a rod (typto: 27:30), 'slapped' (rhapizo: 27:67), 'hit' (paio: 26:68), 'beaten' (dero: 21:35; cf. 21:36), and 'flogged' in Jewish synagogues (mastigoo: 10:17; 23:34) and on Roman military bases (mastigoo: 20:19; phragello: 27:26). Physical abuse and torture of all kinds are clearly considered acceptable as judicial or extra-judicial punishment by Jewish and Roman authorities alike within the world of Matthew's narrative.

And beyond physical abuse and torture lies the ultimate social sanction, the judicial execution or extra-judicial murder of the righteous ones. Matthew's narrative is replete with references to such judicial or extra-judicial killings; and the grim vocabulary of violent death ranges widely. Death at the hands of Jewish or Roman authorities is frequently depicted with the simple metonym 'blood' [haima] or 'blood that is shed/poured out' [haima ekchynnomenon]: 'the blood of the prophets' (23:30); 'all the righteous blood shed on earth' (23:35); 'the blood of righteous Abel' (23:35); 'the blood of Zechariah, son of Barachiah' (23:35); 'my blood ... which is poured out' (26:28); 'this man's blood // his blood' (27:24, 25). ${ }^{26}$ Death by official violence is likewise depicted as 'seeking the life' of another (zeteo ten psychen: 2:20) or, from the opposite point of view, 'losing one's life' (apollymi ten psychen: 10:39; 16:25) or 'giving one's life' (didomi ten psychen: 20:28). The powers that be, whether Jewish or Roman, plot to 'destroy' (apollymi: 2:13; 12:14; 27:20) the righteous ones and go to great lengths to carry out their conspiracies to 'kill' them (anaireo: 2:16). After they have arrested and tried the righteous ones, they pronounce them as 'deserving death' (enochos thanatou: 26:66) and 'condemn them to death' (katakrino thanatoi: 20:18; 27:3).

Framed in broad and general terms the authorities then 'put [the righteous] to death' (thanatoo: 10:21; 26:59; 27:1), ${ }^{27}$ ' kill'

25.See footnote 16 .

26.Cf. 27:4, where Judas refers to the 'innocent blood' [haima athoon] that he has 'handed over (DJW)'.

27.Cf. 15:4, where, according to Jewish law (Ex 21:17; Lv 20:9), the one who speaks evil of father or mother 'must surely die' [thanatoi teleutato]. them, ${ }^{28}$ 'murder' them (phoneuo: 23:31, 35; cf. 2 Chr 24:20-21), or 'do whatever they please' to them (17:12), an unmistakable euphemism for an ugly and brutal execution (14:8-11). And for his part Herod the Jewish client king mounts a massive and vicious pre-emptive strike against the young children of Bethlehem in a desperate attempt to 'kill' his rival (anaireo: 2:16). Depicted in specific terms the Jewish authorities are portrayed as 'stoning' their victims (lithoboleo: 21:35; 23:37; cf. 21:36), ${ }^{29}$ whilst Herod the tetrarch, in a gruesome act of political expediency, 'beheads' his prisoner (apokephalizo: 14:10; cf. 14:8, 9, 11). The Roman authorities, for their part, 'crucify' ${ }^{30}$ their prisoners on wooden 'crosses' ${ }^{31}$ that the condemned themselves or other conscripted civilians are forced to 'take up' or 'carry' (lambano: 10:38; airo: 16:24; 27:32) to the place of execution.

Beyond judicial and extra-judicial killings the righteous ones of Matthew's narrative ultimately face the massive terror and disruption of international warfare. In depicting the events preceding the 'end of the age' $(24: 3,6,13,14)$ Jesus speaks of chaotic conflict - 'wars and rumors of wars' (polemos: 24:6) - in which nations and kingdoms will 'rise' against each other (egeiro: 24:7). This international conflict will be characterised by 'famines' (limos: 24:7), natural disasters such as 'earthquakes' (seismos: 24:7), the desecration of sacred spaces by foreign military incursions (24:15), ${ }^{32}$ the urgent and difficult 'flight' of refugees from war-torn heartlands to the safety of the mountains (pheugo: 24:16; cf. 24:17-20), and 'suffering' of cosmic proportions (thlipsis: 24:21, 29; cf. 24:22). For the righteous ones of Matthew's narrative 'suffering violence' has been a constant reality ever since the murder of 'righteous Abel' (23:35; cf. Gn 4:8-11) at the beginning of time; and they will continue to live this reality throughout history all the way to the cosmic 'suffering' that precedes the 'end of the age' (24:4-29).

To ask about the causes of this unrelenting violence is to look in two directions simultaneously, both toward the actions of the righteous ones themselves and toward the corresponding responses of those who oppose them. For the righteous ones the picture is unambiguous. Suffering comes to them precisely as they go about the tasks of their vocation and precisely due to these vocational activities. ${ }^{33}$ It is in the course of the duties that they are 'sent ${ }^{\prime 34}$ to carry

28.anaireo: 2:16; apokteino: 10:28; 14:5; 16:21; 17:23; 21:35, 38, 39; 22:6; 23:34, 37; 24:9; 26:4. Cf. 21:36.

29.See also 2 Chronicles 24:21, where Zechariah (Mt 23:35) is likewise 'stoned' to death (LXX: lithoboleo).

30.stauroo: 20:19; 23:34; 26:2; 27:22, 23, 26, 31, 35, 38; 28:5.

31.stauros: $10: 38 ; 16: 24 ; 27: 32,40,42$.

32.From the perspective of Matthew's readers Jesus' reference to 'the desolating sacrilege standing in the holy place' clearly points to the desecration of the Jewish temple by the Roman army, an historical event in 70 CE of which Matthew's readers were intensely aware. Similar proleptic depictions of the destruction of Jerusalem and its temple lie in Jesus' parable of the king who gives a wedding banquet for his son (22:7) and in Jesus' warning to Jerusalem that 'your house is left to you desolate' (23:38).

33.See footnote 6. For a wider discussion of the relationship between mission and suffering see Dorothy Jean Weaver, 'As sheep in the midst of wolves: Mission and peace in the Gospel of Matthew', in M.H. Schertz \& I. Friesen (eds.), Beautiful upon the Mountains: Biblical Essays on Mission, Peace, and the Reign of God, (Herald Press, Scottdale, PA, 2003), pp. 123-143.

34.apostello: 10:16; 21:34, 36, 37; 22:3, 4; 23:37. 
out that the righteous ones encounter persecution and death; their 'sending' itself is defined in terms of the unavoidable suffering faced by 'sheep [in] the midst of wolves' (10:16; DJW). The vocation for which these righteous ones suffer includes verbal tasks: 'proclaiming' the arrival of the kingdom of heaven (euangelizomai: 10:7 cf. 10:16), 'inviting' people to the wedding banquet for the king's son (kaleo: 22:3-4 cf. 22:5-6), fulfilling the prophetic ministry of 'Elijah' (17:9-12a cf. 17:12b), pronouncing prophetic judgement on the sins of the people of God (2 Chr 24:20 cf. Mt 23:35//2 Chr 24:21), and speaking fearless truth to the powers that be (14:4 cf. 14:2-3, 8-11; 26:63-64 cf. 26:65-66). The vocation for which the righteous ones suffer also includes deeds of power as well as everyday acts of faithfulness: 'restoring' physical wholeness to broken bodies (apokathistemi: 12:13; cf. 12:14), offering acceptable sacrifices to God (Gn 4:2-5 cf. Mt. 23:35//Gn 4:8-11), living a life of 'righteousness' (dikaiosyne: 5:10), in parabolic language 'collecting the produce' of the landowner on his behalf (lambano tous karpous: 21:34 cf. 21:35, 36), 'following' Jesus (akoloutheo: 16:24a cf. 16:24b), and living life on his 'account' (heneken emou: 5:11; 10:18), in his 'name' (dia to onoma mou: 10:22; 24:9), and as 'those of his household' (oikiakoi autou: 10:25). As Matthew makes clear to his readers, God's righteous ones suffer at the hands of their opponents precisely because of their faithfulness and obedience to the call of God.

For those who oppose the righteous ones of Matthew's narrative the picture is one of diametrical opposites. Here the causes of violence reflect a gamut of negative human impulses and paint a portrait of human weakness and brokenness. Matthew spells out some of these causes explicitly through his omniscient narrator and depicts other causes implicitly through his narrative rhetoric.

Prominent amongst these causes is the primal emotion of fear. Herod the king is 'frightened' (tarasso: 2:3) when he hears of 'the child who has been born king of the Jews' $(2: 2)$. It is this urgent fear of his political rival that fuels his initial conspiracy against the life of the child (2:4-8) and its vicious consummation in the massacre of the children of Bethlehem $(2: 13,16)$. Herod the tetrarch, for his part, is depicted as a man consumed by the fear of everyone around him: John the Baptist (14:1-2, 3-4), the crowd (phobeomai: 14:5), Herodias and her daughter (14:6-11), the guests at the party (14:6-11). And this all-consuming fear leads Herod to carry out a gruesome act that he 'grieves' (lypeo: 14:9) even as he 'commands' it to be done (keleuo: 14:9). The authorities in Jerusalem, both Jewish and Roman, exhibit deep fear of the Jerusalem crowds and the 'riots' (thorybos: 26:5; 27:24) of which they are capable. This fear (26:5) is a prime factor in the conspiracy of 'stealth' (dolos: 26:4) that the chief priests and elders instigate against Jesus. This same fear (27:24a) ultimately drives Pilate to take an expedient political act for which he vainly seeks to establish his 'innocence' (athoos eimi: 27:24b) even as he 'hands [Jesus] over' (paradidomi: 27:26) to be crucified. Clearly fear is a hugely debilitating emotion, as Matthew portrays it, one that consumes the individuals caught in its grip and drives them into violent actions that defy their own better wisdom $(27: 18,19,23)^{35}$ or even their own wishes (14:9). ${ }^{36}$

A second prominent cause of the violence against the righteous ones in Matthew's narrative is jealousy and the political rivalry associated with it. Pilate knows that the Jewish authorities have handed Jesus over to him out of 'jealousy' (phthonos: 27:18). Jesus paints this same portrait of the Jewish authorities as he depicts the conspiracy of the wicked tenants against the son of the landowner (21:38): 'This is the heir [kleronomos]; come, let us kill him and get his inheritance [kleronomia]'. The chief priests and elders prove Pilate and Jesus right as they fret over the 'riot' (thorybos: 26:5) that will ensue if they arrest Jesus, whom they implicitly acknowledge as highly popular, during the festival.

Anger is a third prominent causal factor in the violence against the righteous ones. The final precipitating cause in the massacre of the children of Bethlehem is Herod's 'infuriation' (thymoomai: 2:16) at being 'tricked' (empaizo: $2: 16)$ by the magi in an act that thwarts his initial conspiracy against his child-rival (2:12; cf. 2:7-8). Jesus' uncanny ability to outwit the religious leaders at verbal sparring (12:912; 21:23-22:45) - in spite of their best efforts to 'test' him (peirazo: 22:35) and 'entrap' him in his words (pagideuo: 22:15) - leaves them 'amazed' (thaumazo: 22:22), 'silenced' (phimoo: 22:34) and incapable of 'answering' (apokrinomai: 22:46a) or 'asking' (eperotao: 22:46b) Jesus anything more. It also leaves them angry enough to wish for his 'arrest' (krateo: 22:46) and conspire to 'destroy' him (apollymi: 12:13). ${ }^{37}$

Additional factors leading to acts of violence against the righteous of Matthew's narrative are the avaricious search for financial gain $(26: 14-16 ; 27: 3-10)$ and the callous and even sadistic delight in entertainment at any cost (27:27-31). As Matthew depicts him, Judas is clearly motivated by the desire for money ('What will you give me [didomi]': 26:15a) as he goes to the chief priests with his scheme for Jesus' arrest (paradidomi: $26: 15 b$ ). He is similarly motivated by the thirty pieces of silver that they 'pay' him (histemi: 26:15c) as he carries out his part of the plot: 'And from that moment he began to look for an opportunity to [hand him over: paradidomi]' (26:16). The Roman soldiers, for their part, appear to be motivated by callous delight in mocking and torturing a helpless prisoner who is at their mercy (27:27-31). Their detailed efforts to create a mock-royal scenario, complete with clothing, crown, scepter and homage (27:28-29), suggest the actions of soldiers who seek elaborate entertainment to

35.Pilate is aware that the religious leaders are acting out of 'jealousy' (27:18). He learns from his wife that Jesus is an 'innocent' man (27:19). And he knows for himself that Jesus has done no 'evil' (27:23).

36.Thus Herod's 'grieving' (14:9) at the act he nevertheless carries out. For a wider discussion of the character of the three political leaders in Matthew's narrative see Dorothy Jean Weaver, 'Power and Powerlessness: Matthew's Use of Irony in the Portrayal of Political Leaders', in D.R. Bauer \& M.A. Powell (eds.), Treasures New and Old: Recent Contributions to Matthean Studies, Symposium Series, no. 1, (Scholars Press, Atlanta, 1996), pp. 179-196.

37.Cf. 2 Chronicles 24:20-21, where anger at Zechariah's words of judgment against the people of Judah likewise appears to be the predominant factor leading to his stoning death. 
alleviate their boredom at life in the barracks. Their physical abuse of Jesus (27:29-30) gives evidence of sadistic pleasure at the pain and humiliation of others.

The picture is grim for the righteous ones of Matthew's narrative. They have faced consistent suffering throughout history at the hands of their opponents, both Jewish and Gentile. And Jesus tells them that this situation will continue all the way to the end of the age. Further, they face this suffering not because of their wrongdoing but precisely because of their work on behalf of the kingdom of heaven, the mission that they have been 'sent' to carry out (10:16; $21: 34,36,37 ; 22: 3,4 ; 23: 34)$. It is in short their lives of faithful obedience to God that engender massive fear, jealousy, and anger on the part of their opponents and make the righteous ones victims of avarice and callous brutality.

But this is not the end of the matter, so far as Matthew is concerned. Violence is not the last word and suffering is not the last reality for the righteous ones of Matthew's narrative. If Matthew paints a grim and ugly portrait of the violence suffered by the righteous ones, he paints an equally vivid and frequently surprising portrait of their responses to this violence. Through the words of Jesus and the lived experiences of the righteous ones Matthew depicts for his readers the widely divergent characteristics of faithful response to violence.

\section{The characteristics of faithful response to violence}

As Matthew tells his story, faithful response to violence comprises an entire spectrum of discrete actions ranging from the highly intuitive to the profoundly counter-intuitive and from silence and apparent passivity to bold and fearless public action. This wide spectrum of discrete actions, taken together, then creates an overarching portrait that is multifaceted, complex, and well beyond the ordinary. Matthew paints this complex and extraordinary portrait by way of illustrations both positive and negative.

At the pragmatic end of the spectrum Matthew depicts 'flight' as an obvious, sensible, and divinely-sanctioned response to the threat or the reality of violence. In light of Herod's imminent attempt to 'search for the child, to destroy (apollymi) him' (2:13b), it is none other than the angel of the Lord who instructs Joseph to 'get up, take the child and his mother, and flee (pheugo) to Egypt, and remain there until I tell you' (2:13a). ${ }^{38}$ As Jesus commissions his disciples for ministry, he instructs them, 'When they persecute you (dioko) in one town, flee (pheugo) to the next' (10:23a). ${ }^{39}$ Similarly, as Jesus tells his disciples of the chaos and turbulence that will precede the coming of the Son of Man, he warns them,

38.The motif of 'flight' is also implicit in 2:22, where Joseph is 'afraid' [phobeomai] to return to Judea, is 'warned' [chrematizo] in a dream, and 'goes away (anachoreo) to the district of Galilee' instead.

39.The disciples' 'flight' (10:23a), however, is linked not to their personal safety but rather to their ongoing mission to the Jewish towns and cities: 'For truly I tell you, you will not have gone through all the towns of Israel before the Son of Man comes' (10:23b). See Weaver, Matthew's Missionary Discourse, pp. 99-100.
'So when you see the desolating sacrilege standing in the holy place, ... then those in Judea must flee (pheugo) to the mountains' (24:15-16). He adds:

Pray that your flight (phyge) may not be in winter or on a Sabbath. For at that time there will be great suffering (thlipsis) such as has not been from the beginning of the world until now, no, and never will be.

(Mt 24:20-21)

For his part Jesus himself 'departs' (anachoreo: 12:15) in similar fashion when he learns that the Pharisees have 'conspired against him, how to destroy (apollymi) him' (12:14); and he once again 'withdraws' (anachoreo: 14:13) upon news of the death of John the Baptist. ${ }^{40}$ Clearly, as Matthew sees it, there are times when 'flight' or 'withdrawal' is both appropriate and necessary in the face of present or impending danger. ${ }^{41}$

When appropriate 'flight' is not possible, however, or perhaps even when it is (cf. 24:20-22), Jesus calls his followers to a life of sturdy 'endurance'. In the face of inevitable suffering and death Jesus promises his disciples that the one who endures (hypomeno) to the end will be saved (sozo)' (20:22; 24:13). Such 'salvation' does not, to be sure, imply personal safety in the present moment. The settings that call forth this 'endurance' are ones where 'hatred' [miseo] of the righteous ones is endemic amongst Jews (10:22), Gentiles (24:9), and even former followers of Jesus (24:10) 'because of [his] name' (dia to onoma mou: 10:22; 24:9). They are also settings where close family members or other opponents will 'hand over' (paradidomi: 10:21a; 24:9a) the righteous ones to be 'tortured' (eis thlipsin: 24:9a) and 'put to death' (eis thanaton: 10:21a; thanatoo: 10:21b; 24:9b). 'Endurance' is, accordingly, a stance of sturdy faithfulness to the 'name' and the mission of Jesus to the 'end' [telos] of one's own life. ${ }^{42}$

A life of endurance brings with it, in turn, certain social obligations that serve as established personal or communal rituals linked to suffering and death. One of these rituals is burial. Looking toward his upcoming violent death Jesus commends the woman who has 'poured' very costly ointment on his head (katacheo: 26:7) for 'preparing my body for burial' (pros to entaphisasai me: 26:12). And following the gruesome execution of John the Baptist (14:10-11), John's disciples 'bury' his body [thapto] and 'notify' Jesus (apangello: DJW) of his death.

A ritual, both personal and communal, that is closely associated with burial is the outward expression of grief and lament. In his own editorial response to the horrific massacre of the children of Bethlehem, Matthew invokes the words of Jeremiah 31:15: 'A voice was heard in Ramah, wailing

40.Jesus' 'withdrawal' at the death of John the Baptist (14:13) might, however, best be interpreted not in terms of 'flight' but rather as an act of 'mourning' over John's death and preparatory to a time of 'prayer' (14:23). See the discussion of 'grief and lament' below.

41.But when 'flight' implies the 'desertion' of Jesus, it is for Matthew no longer appropriate but rather an act of cowardice and failure: 'Then all the disciples deserted him (aphiemi and fled (pheugo)' (26:56).

42.The obvious counterpart to 'endurance' is for Matthew the human tendency to 'fall away' or 'become deserters' (skandalizomai: $13: 21 ; 26: 31 ; 33$ ), a failure to which prey (26:33, 35 cf. 26:56). 
(klauthmos) and loud lamentation (odyrmos polys), Rachel weeping (klaio) for her children; she refused to be consoled (parakaleo), because they are no more' (2:18). Pointing metaphorically toward his violent demise, Jesus speaks of his disciples as those who will mark that event by 'mourning' and 'fasting' (9:15):

The wedding guests cannot mourn (pentheo) as long as the bridegroom is with them, can they? The days will come when the bridegroom is taken away from them (apairo, and then they will fast (nesteuo).

In the Garden of Gethsemane Jesus laments his own death in audible and visible fashion: 'grieving deeply ... even to death' (lypeo: 26:37; perilypos ... thanatou: 26:38), 'being agitated' (ademoneo: 26:37), and 'throwing himself on the ground' (literally 'falling on his face': pipto epi prosopon autou: 26:39). And as he hangs dying on the cross Jesus 'cries out with a loud voice' (boao ... phonei megalei: 27:45; cf. 27:50) in the words of Psalm 22, a psalm of lament: 'My God, my God, why have you forsaken me?'

For Matthew it is clear that the personal and communal rituals of burial and lament are crucial responses for those who suffer violence. Preparing the 'soul' (psyche: 26:38; DJW) and the 'body' (soma: 26:12) for death and 'weeping' (2:18) and 'mourning' (9:15) for those who have died are often the only options available to the righteous ones overtaken by the violence of the powerful. Jesus' words to his disciples in the Garden of Gethsemane make it clear that 'grieving' is in fact the calling of the entire community of righteous ones as they gather around the suffering individual: 'I am deeply grieved, even to death; remain here (meno) and stay awake (gregoreo) with $m e^{\prime}$ (26:38; cf. 26 [author's emphasis]). ${ }^{43}$

Flight, endurance, and lament represent pragmatic and/ or instinctive responses to violence. These responses come instinctively to mind in the moment of crisis (flight) or may happen without any formal thought at all (lament). Or these responses make pragmatic sense to the righteous ones (endurance) in a world where violence cannot be avoided. But on the other end of the spectrum Matthew points his readers toward responses to violence that are highly counterintuitive in character. These responses by their very nature demand careful thought and represent acts of the will that run directly contrary to human instinct. At the same time these responses are grounded in the character and the enabling power of God.

One such counter-intuitive response is reflected in Jesus' extraordinary negative injunctions against 'worry' (merimnao: 10:19), 'fear' (phobeomai: 10:26, 28a, 31), and 'alarm' (throeomai: 24:6) and his equally extraordinary positive injunction to 'rejoice' (chairo) and 'be glad' (agalliao) in the face of 'persecution' and verbal abuse (5:11-12). Depicting threatening legal contexts where his disciples will one day be handed over to Jewish 'councils' and dragged before 'governors and kings' to stand trial and bear 'testimony'

43.This is, however, a calling that Jesus' disciples miss as they 'sleep' (katheudo: 26:40 $43,45)$ rather than 'staying awake' (gregoreo: $26: 38,40,41$ ).
(10:17-18), Jesus nevertheless calls his followers 'not to worry' about their legal defense: 'When they hand you over, do not worry about how you are to speak or what you are to say' (10:19). Envisioning confrontational settings in which others will 'malign' the disciples (10:25) and life and death settings in which people will 'kill' their 'bodies' (10:28), Jesus challenges his followers to 'have no fear' of their opponents (10:26, 8a, 31). Pointing toward the chaos and violence of international warfare before the end of time (24:6-8), Jesus encourages his disciples 'not to be alarmed' (10:6). In place of their worry, fear, and alarm, Jesus calls his disciples to 'rejoice and be glad' as they face 'persecution' (5:11-12).

In light of the confrontational, dangerous, and even deadly settings depicted, Jesus' injunctions - whether negative or positive - make no sense on the human level. But viewed from a divine vantage point, these injunctions take on a totally new character. Jesus' disciples can release their 'worries' about legal defense because their words will come to them as divine gift:

For what you are to say will be given to you at that time; for it is not you who speak, but the Spirit of your Father speaking through you.

(Mt 10:19b-20)

They can release their 'fears' of verbal abuse since none other than God is at work through their own proclamation (10:27) to 'uncover' hidden truth and 'make it known' (10:26). ${ }^{44}$ They can release their 'fears' of death in the confidence that God their 'Father' has 'counted the hairs of their head', accords his children infinite 'value', and will be with them in their suffering, since nothing happens 'apart from' him (10:2931). They can release their 'alarm' at the turbulent course of human events in the sure knowledge that the 'end' of history will proceed on God's timetable (24:6-8; cf. 24:14). They can 'rejoice and be glad' at their sufferings, since it is God who will ultimately 'reward' them 'in heaven' for their faithfulness (5:12). Accordingly, it is the character of God and God's power at work within human history and beyond that give ultimate meaning to Jesus' extraordinary injunctions.

A second counter-intuitive response to violence, one that corresponds inversely to Jesus' negative injunctions against worry, fear, and alarm, is that of bold proclamation and the courage to speak truth to power. As Matthew depicts it, righteous ones who are no longer consumed by worry or paralysed by fear of the violence to come can exhibit the courage of their own moral convictions and can proclaim the truth of God boldly, regardless of the personal consequences that they may face. John the Baptist exhibits just such courage of conviction as he issues persistent and blunt rebukes to Herod the tetrarch concerning Herod's liaison with Herodias, the wife of his brother Philip: 'It is not lawful for you to have her' (14:4). ${ }^{45}$ John's courage of conviction lies beyond dispute. To speak blunt truth to political leaders is a highly dangerous proposition in any world and surely in

44.See Weaver, Matthew's Missionary Discourse, pp. 107-108.

45.The imperfect verb elegen implies that John has been repeating this rebuke over and over. 
the world that John inhabits; and to do so repeatedly proves in fact to be an affront deemed worthy of imprisonment and death $(14: 3,5)$.

Jesus exhibits the same courage of conviction in an equally dangerous setting. When Caiaphas puts Jesus 'under oath before the living God' to reveal his identity as 'the Messiah, the Son of God' (26:63), Jesus responds with a fearless and powerful affirmative proclamation ${ }^{46}$ that brings down on his head the charge of 'blasphemy' from the high priest (26:65), the sentence of 'death' from the members of the Jewish council (26:66), and ugly verbal and physical abuse (26:67). Jesus clearly views his calling as that of speaking truth to power, regardless of the violent consequences.

Jesus' disciples, for their part, have the same vocation. As Jesus prepares his disciples for mission, he calls them to fearless and highly public proclamation precisely in those contexts where their lives are endangered by those who will 'malign' them (10:25) and 'kill their bodies' (10:28): 'What I say to you in the dark, tell in the light' (eipate en toi photi: 10:27a); 'and what you hear whispered, proclaim from the housetops' (keryxate epi ton domaton: 10:27b). In the next breath (10:32) Jesus affirms those who 'acknowledge' him 'before others' [homologeo ... emprosthen ton anthropon], an implicit warning that such an 'acknowledgement' will not take place without significant personal cost. ${ }^{47}$ As Jesus alerts his disciples, it is precisely within the context of the horrific violence that precedes the end of the age (24:9-10) that 'this good news of the kingdom will be proclaimed (kerysso) throughout the world, as a testimony (martyrion) to all the nations' (24:14a). Then and only then will the end come (24:14b). Fearless proclamation in the face of deadly violence will be the calling and the challenge for Jesus' disciples throughout history to the very end. ${ }^{48}$

But beyond the call to fearless proclamation lies what is surely an even more radical call to response in the face of violence. In the Sermon on the Mount $(5: 39,44)$ Jesus issues corresponding challenges to his disciples 'not to resist' [me antistenai] the 'evildoer' [poneros] but rather to 'love' [agapao] your 'enemies' [echthros] and 'pray' [proseuchomai] for 'those who persecute you' [dioko]. The juxtaposition of vocabulary in these corresponding commands is breathtaking in its audacity. These commands, each in their own way, are profoundly counter-intuitive, presenting themselves to Jesus' hearers and to Matthew's readers as nothing short of scandalous. ${ }^{49}$

46.'You have said so. But I tell you, from now on you will see the Son of Man seated at the right hand of Power and coming on the clouds of heaven' (26:64).

47.This is, however, a cost that Peter is not willing to pay when he is confronted in the courtyard of the high priest (26:69-75). Instead of 'acknowledging' Jesus (homologeo: 10:32) before the bystanders in the courtyard, Peter 'denies' Jesus (arneomai: 26:70, 72; cf. 26:74) just as Jesus has challenged the disciples not to do (arneomai: 10:33) and just as Jesus has warned Peter that he is about to do (aparneomai: 26:34).

48. Note, however, Jesus' 'silence' (siopao: 26:63) in the face of false witnesses (26:59, $60)$ and his failure to 'answer' (apokrinomai: 27:12, 14) the many accusations brought against him $(26: 12,13)$. Clearly there are also appropriate times for silence.

49.Cf. Jesus' pointed appeal to the disciples of John the Baptist (11:6): 'And blessed is [the one] who takes no offense at me (skandalizomai).' Jesus' words in 5:39 are surely cause for 'offense'.
The call 'not to resist an evildoer' (5:39) represents Jesus' repudiation of the long-established Jewish law of retaliation, the lex talionis setting forth the rules by which the community was to respond in kind to an act of 'evil' done in its midst. ${ }^{50}$ Jesus' radical reversal of this time-honored community response to violence appears at first glance to be total capitulation to the 'evildoer'. But the negative command ('Do not resist'), which at face value appears completely passive in character, gives way to an entire sequence of imperatives that are both genuinely active and shockingly unanticipated $(5: 39 b-41)^{51}$ :

But if anyone strikes you on the right cheek, turn the other also; and if anyone wants to sue you and take your coat, give your cloak as well; and if anyone forces you to go one mile, go also the second.

Within the framework of Jesus' overall saying (5:38-42) it is these active imperatives $(5: 39 b-41$; cf. $5: 42)$ that serve to interpret the negative command (5:39a) and give it meaning. Accordingly, Jesus' call 'not to resist the evildoer' is in fact a bold challenge to active response of a profoundly nonviolent but equally provocative character. ${ }^{52}$ And these nonviolent responses, shocking as they may appear, in fact put initiative for the very first time into the hands of the righteous ones rather than those of the 'evildoer'. As long as the 'law of retaliation' is in force, it is only the 'evildoer' who has the power of initiative, since those who suffer violence can do nothing but respond in kind. But with Jesus' stunning repudiation of the lex talionis, the righteous ones now have the authority to take bold yet nonviolent initiatives in response to the violence that they encounter..$^{53}$

Jesus' call to 'love your enemies and pray for those who persecute you' (5:44) and his corresponding blessing on the 'peacemakers' (eirenopoioi: 5:9) reflect the obverse of the command 'not to resist an evildoer' (5:39a). The negative formulation 'not to resist' finds its ultimate meaning in the positive commands to 'love', 'pray', and 'make peace'. ${ }^{54}$ These astonishing commands, profoundly counter-intuitive as they are, have their basis in the very character of God and their ethical appeal in the call to 'be children of God [your heavenly Father]' (5:9; cf. 5:45, 48: DJW). Because God 'makes his sun rise on the evil and on the good and ... sends rain on the righteous and the unrighteous' (5:45b), Jesus calls his disciples to 'love' and 'pray for' those they would rather hate (cf. 5:43). Because God's mission is to make peace, ${ }^{55}$

50.For a wider discussion of this saying of Jesus (5:38-42) in light of its Deuteronomic counterpart (Dt 19:15-21), see Weaver, "Transforming Nonresistance".

51.The parallel commands of 5:42 complete Jesus' list of responses; but they do not represent responses to violent acts in the same way as the commands of 5:39b-41.

52.The clear implication of these illustrative responses to violence is that they will not only break the vicious cycle of action and reaction, but that-in the honor or shame culture of first century Palestine - they will also shame the perpetrators of violence into an awareness of the 'evil' of their own actions.

53.The disciple who draws a sword in the Garden of Gethsemane and attacks the slave of the high priest (26:51) is clearly not yet courageous enough for Jesus' bold command 'not to resist the evildoer'. Accordingly Jesus instructs him to 'put [his] sword back into its place' (26:52a), warning him that the only other alternative is in effect that of the lex talionis: 'For all who take the sword will perish by the sword' (26:52b).

54.Cf. Jesus' similar appeal $(5: 25)$ to 'come to terms' [eimi eunoon] with your accuser [antidikos].

55.Whilst it is not stated explicitly, this is the clear implication of the 'blessing' on the peacemakers in 5:9. 
Jesus calls down a 'blessing' on those who are 'peacemakers' (5:9). Where the character of God is in focus, there the empowerment of God is likewise present. When Jesus calls his disciples to 'be children of God, your heavenly Father', Jesus' words do not imply 'bootstrap' theology but rather divine empowerment. The same 'Father' whose 'Spirit' will be speaking through the disciples when they need words in crucial situations (10:19-20) will likewise empower his 'children' to respond to violence with 'love', 'prayer', and 'peacemaking'.

But without question the most prominent of the counterintuitive responses to violence reflected in Matthew's narrative is obedient commitment to the mission of God in a dangerous world and the correlative willingness to suffer violence because of that mission if necessary. Such commitment and willingness to suffer is reflected above all in Jesus' repeated words about the divine necessity of his own suffering. During his Galilean ministry Jesus announces to his disciples that he 'must (dei) go to Jerusalem and undergo great suffering (polla pathein) ... and be killed (apokteino)' (16:21 [author's emphasis]). ${ }^{56}$ Jesus rebukes the disciple who seeks to defend him violently in the Garden of Gethsemane with the words (26:53-54 [author's emphasis]):

Do you think that I cannot appeal to my Father, and he will at once send me more than twelve legions of angels? But how then would the scriptures be fulfilled (pleroo), which say it must happen in this way (houtos dei genesthai)?

And to the crowd who has come to arrest him he says (26:5556; [author's emphasis]):

Day after day I sat in the temple teaching, and you did not arrest me. But all this has taken place, so that the scriptures of the prophets may be fulfilled (pleroo).

Clearly Jesus views his suffering as a necessary component of the overarching mission to which he has been 'sent' by God (apostello: 10:40; 15:24; 21:37), namely a mission to 'fulfill the scriptures' (26:54,56; cf. 5:17). Jesus is obedient to this divine calling. When Peter tests this commitment and tempts Jesus to avoid suffering (16:22), Jesus rebukes Peter sharply and charges him with 'setting your mind not on divine things but on human things' (16:23). ${ }^{57}$ When the moment of crisis comes, Jesus responds obediently, accepting God's 'will' over his own personal desires (thelo/thelema: 26:39b, 42b; cf. 26:44) and committing himself to 'drink the cup' that has been set before him (poterion pino: 26:39a, 42a; cf. 20:22, 23; 26:44). As he hangs dying on a Roman cross Jesus refuses the temptation posed by the religious leaders who taunt him to 'save [himself]' (sozo: 27:40; cf. 27:42) ${ }^{58}$ and 'come down' from the cross (katabaino: 27:40,42).

The same unswerving commitment to the mission of God in the face of certain and unavoidable suffering, is also

56.Cf. 17:12, 22-23; 20:17-19, 22-23; 26:1-2.

57.Cf. the temptations that Jesus faces as he hangs on the cross, namely to 'save' himself (sozo: 27:40a, 42a) and to 'come down from the cross' (katabaino: 27:40b; $42 \mathrm{~b})$. Here Jesus does not rebuke the tempters but as with Peter he does not yield to their temptations.

58. Here Jesus puts to the test his own challenge to his disciples: 'For those who want to save their life will lose it, and those who lose their life for my sake will find it (16:25; cf. 10:22b//24:13). reflected in the past lives of the prophets of Jewish history and projected into the future lives of Jesus' own disciples. ${ }^{59}$ In his parable about the landowner and the wicked tenants (21:33-46) Jesus depicts the prophets as the slaves who are 'sent' [apostello] by the landowner to 'collect his produce' [lambano tous karpous: 21:34; cf. 21:36]. Even when it becomes clear that the first crew of slaves thus 'sent' has suffered violence and death on account of their mission (21:35), the second crew of slaves nevertheless goes out obediently as 'sent' by the landowner (21:36a) and meets with the same fate (21:36b). In similar fashion Jesus tells a story about a king who 'sends' [apostello] his slaves to 'invite' [kaleo] people to the wedding of his son (22:1-14), a pointed reference to Jesus' own disciples and their mission on behalf of the kingdom of heaven (10:7). Here as well the slaves who are 'sent' respond in obedience to their calling (22:3a, 4), even as it becomes apparent that their mission is rejected (22:3b) and their very lives endangered (22:5). Jesus paints the same portrait of faithful obedience when he says to the Jerusalem leaders:

Therefore I send you (apostello) prophets, sages, and scribes, some of whom you will kill and crucify, and some you will flog in your synagogues and [persecute] from town to town.

(Mt 23:34; DJW; cf. 10:23)

As Matthew sees it, unshakeable commitment to the dangerous mission of God and willingness to accept the suffering that this entails is a prime characteristic of faithful response to violence.

Finally, in light of the wide array of faithful responses to violence depicted in Matthew's narrative, actions ranging from flight out of harm's way (2:13-23; 24:15-22) to bold, nonviolent initiatives in the very face of 'evil' (5:38-48), Matthew offers his readers two crucial clues to discerning the right response in any given moment. The first of these clues lies in the urgent call to be attentive to one's surrounding circumstances. As Jesus sends his disciples out 'like sheep into the midst of wolves' (10:16a), he enjoins them to be at one and the same time 'wise (phronimoi) as serpents' and 'innocent (akeraioi) as doves' (10:16b). This seemingly paradoxical imperative is in fact a call to keep one's eyes and ears open to impending danger $(2: 22)^{60}$ and to 'beware' of people and the violence they will unleash (prosecho: 10:17a). It is also a call to resistance against false loyalties: the public pressure to 'believe' (pisteuo: 24:23, 26b) propaganda concerning 'false messiahs' and 'false prophets' (24:24a); the human propensity to be 'misled' (planao: 24:24c) by the public campaign of 'great signs and wonders' carried out by these charlatans (24:24b); and the powerful urge to 'go out' (exerchomai: 24:26a) and join their entourage. It is just such 'wise innocence' or 'innocent wisdom' that will equip Jesus' disciples for responding appropriately in the moment of crisis when violence overtakes them.

59.In the present moment, however, Peter openly exhibits his unwillingness to face suffering as he rebukes Jesus for predicting his passion (16:22). And he once again proves his unwillingness to suffer as he 'denies' Jesus in the courtyard of the high proves his unwillingness to suffer as he denies Jesus in the courtyard of the high priest (26:69-75). The sons of Zebedee, for their part, appear overly optimistic a they glibly announce that they are 'able' $(20: 22 b)$ to 'drink the cup' that Jesus is 'about to drink' (20:22a; cf. 20:23). In fact they, along with the rest of the disciples,
'desert' Jesus and 'flee' when their own lives appear endangered (26:56).

60.Joseph's attentiveness to the danger posed by the rule of Archelaus (2:22a) is affirmed in effect by the divine 'warning' that Joseph receives in a 'dream' (2:22b) 
But just as importantly Matthew's readers hear another urgent call as well, the call to be attentive to the voice and the will of God. The magi $(2: 12)$ and Joseph $(2: 13,22)$ respond to impending violence as they hear and obey the 'angel of the Lord' (2:13) who speaks the words of God to them in 'dreams' (kat' onar: 2:12, 13, 22). ${ }^{61}$ Jesus, for his part, attends to the voice of God through urgent prayer before his crucifixion. In the Garden of Gethsemane Jesus pleads with his Father three times for the 'cup' of suffering to be taken from him (27:39; cf. 27:42,44). But each time and in the very next breath he commits himself, just as he has taught his disciples to do in their own prayers (6:10b), to his Father's 'will'. His first prayer concludes with the words 'Yet not what I want (thelo) but what you want' (27:39) and the second with the petition 'Your will (thelema) be done' (27:42; cf. 27:44).

The crucial significance of this attentiveness to the will of God becomes clear in Jesus' words to Peter, one of his sleeping disciples:

So, could you not stay awake with me one hour? Stay awake and pray that you may not come into the time of [temptation]; the spirit indeed is willing but the flesh is weak.

(Mt 26:40b-41; NRSV footnote [author's emphasis])

Jesus' words are as true for himself as they are for his disciples. Jesus himself faces profound temptation. Whilst his own spirit is willing, he acknowledges that his own flesh is weak. But precisely because he has stayed awake and prayed, he is now empowered to respond faithfully to the violence that will shortly overtake him. ${ }^{62}$ Clearly, as Matthew tells the story, attentiveness to the voice of God, whether in dream or in prayer, is for God's righteous ones the ultimate key to faithful response vis-a-vis the challenges of a violent world.

\section{Suffering violence and the narrative rhetoric of Matthew's gospel}

In his story about Jesus Matthew paints a vivid portrait of a world in which God's righteous ones 'suffer violence' (11:12) at the hands of brutal and powerful opponents precisely as they go about their mission on behalf of the kingdom of heaven and precisely because they do so. The violence they suffer is in many cases deadly. As a result the righteous ones, who have in fact been 'sent out' to their work like 'sheep into the midst of wolves' (10:16), ${ }^{63}$ encounter death in the commission of their appointed task. This narrative portrait is a bleak one, taken at face value and read at the 'lower level' of Matthew's narrative. ${ }^{64}$ The surface implications of

61.Cf. the actions of Pilate's wife, who seeks, in vain as it turns out, to forestall impending violence against Jesus in response to a 'dream' that she has had concerning him (kat' onar: 27:19). See Dorothy Jean Weaver, "“Thus You Will Know Them by Their Fruits": The Roman Characters of the Gospel of Matthew', in J. Riches \& D.C. Sim (eds.), The Gospel of Matthew in Its Roman Imperial Context, (T \& T Clark International, London, 2005), pp. 119-121.

62.The disciples, to the contrary, have slept through their prayer time $(26: 40,43,45)$ and are completely unprepared to deal appropriately with the violence that overtakes Jesus and threatens their own lives. They respond by striking back with the sword (26:51), deserting Jesus and fleeing (26:56), and denying any acquaintance with Jesus (26:69-75).

63.Cf. $21: 34,36,37 ; 22: 3,4 ; 23: 34,37$.

64.D.C. Muecke in The Compass of Irony (Methuen, London, 1969) defines irony (pp. 19-20) as a 'double-layered or two-storey phenomenon' in which 'the lower level is the situation either as it appears to the victims of irony ... or as it is deceptively presented by the ironist' and 'the upper level is the situation as it appears to the observer or the ironist'. this portrait are that violence wins the day, God's righteous ones are defeated by the powers of evil, and the kingdom of heaven is diminished by its opponents.

But these 'lower level' implications prove entirely unreliable within the thoroughgoing irony of Matthew's narrative. Whilst Matthew paints a vivid and convincing 'lower level' portrait of the power of the violent and the impact of their violence, he simultaneously subverts his own effort with an astonishing 'upper level' portrait that gives the lie to apparent reality. Matthew's 'upper level' portrait is one that turns conventional wisdom on its head and redefines the significance both of violence and of suffering.

In the world of Matthew's story military empire and its subsidiaries are the supreme powers of the day ${ }^{65}$ and statesanctioned violence is the standard tool for maintaining such empire $(2: 13-23 ; 14: 1-12 ; 27: 1-2,11-54)$. The religious authorities of the Jewish world, for their part, also wield significant power and carry out violence in their own sphere. Against this backdrop Matthew paints a stunning portrait of the powers that be, both Roman and Jewish, unmasking the utter futility of their violence and ridiculing their very image as powerful leaders. ${ }^{66}$

Herod the king, for all of his political clout (2:3), his power of command (2:4-6, 7-9), and his military might (2:16), cannot achieve his single goal, the death of his new-born rival (2:7-8, $13,20)$. Instead he is thwarted at every step of the way by the 'angel of the Lord' who warns others in advance about Herod's evil designs so that they can take evasive actions $(2: 12,13-14 ;$ cf. $2: 19-21,22)$. And in the end it is Herod who lies dead rather than the 'child' he has been seeking to kill (2:19-20). Herod the tetrarch, ruler of the Galilee, shows up in Matthew's narrative as a paranoid weakling, pulled now this way and now that by his fear of all the other characters: John the Baptist (14:1-2, 3-4), the crowd (14:5), Herodias and her daughter (14:6-11), and the guests at the party (14:9). Even after he has employed the ultimate violence at his disposal and executed his nemesis (14:9), he finds himself newly haunted by an even more powerful 'John the Baptist' who has been 'raised from the dead' (14:1-2). Pilate, governor of Palestine and the highest ranking Roman on Matthew's narrative stage, unleashes the full violence of empire against Jesus 'the king of the Jews' and turns him over for crucifixion (27:26), only to discover (or perhaps not!) that the superpower of the world has been upstaged by a divine coup in which God has raised Jesus from the dead and emptied the tomb in which he was laid (28:14). For their part the Jewish religious leaders come up as 'short-handed' as the powers of empire. For all their scheming and conspiracy $(12: 14 ; 21: 45-46 ; 26: 3-$ $5,14-16)$, their 'false witnesses' (26:59-61), their accusations against Jesus (27:12-14), their public manipulation of the crowds (27:20-23), and their private manipulation of Pilate

65.For a wider discussion of the portrayal of empire within Matthew's Gospel, see Weaver, D.J., 2009, "They did to him whatever they pleased": The exercise of Weaver, D.J., 2009, "They did to him whatever they pleased". The exercise of political power within Matthew's narrative', HTs Teologiese Studies/Theological Studies 65(1), Art. \#319, 13 pages. doi: 10.4102/hts.v65i1.319; Weaver, “"Thus You Will Know Them by Their Fruits"'.

66.For a wider discussion of this theme, see Weaver, 'Power and Powerlessness'. 
(27:62-66; 28:14), the Jewish leaders end up with an empty tomb for which they have no good explanation (28:11-15) and a 'last deception' that is for them truly 'worse than the first' (27:64). As Matthew paints the portrait, the violence of the powerful is singularly ineffective in achieving the goals of those who employ it. To the contrary the violence of the powerful serves only to reveal the limits of their power and to make a mockery of their trust in the use of violent force.

Matthew's portrait of the suffering of the righteous is as extraordinary and paradoxical as his portrait of the violence of the powerful. This portrait is filled with images of the vindication of the righteous in the very face of their sufferings and precisely because of them. Many of these images come from the words of Jesus. In his inaugural address to his disciples Jesus pronounces a 'blessing' on those who are 'persecuted for righteousness' sake' (5:10) and those whom people 'revile', 'persecute', and against whom they falsely speak "all kinds of evil" on account of Jesus himself $(5: 11){ }^{67}$ Jesus promises these righteous ones the inheritance of the 'kingdom of heaven' (5:9) and 'great reward' in that realm (5:12). And he designates those who 'love their enemies', 'pray for their persecutors' and live as 'peacemakers' as 'children of God, their heavenly Father' (5:9 and 5:48; cf. 5:45). As John the Baptist languishes in Herod the tetrarch's prison (4:12), Jesus heaps commendation on his head, announcing that:

Among those born of women no one has arisen greater than John the Baptist' (11:11). In almost the next breath he adds pointedly, 'From the days of John the Baptist until now the kingdom of heaven has suffered violence, and the violent take it by force.

(Mt 11:12)

After John the Baptist's death Jesus once again commends John, identifying him as the eschatological Elijah: 'But I tell you that Elijah has already come' (17:12a). Once again he associates his commendation of John with John's suffering: 'And they did not recognize him, but they did to him whatever they pleased' (17:12b). As he prepares his disciples for their mission work on behalf of the kingdom of heaven, Jesus promises that when his followers are put on trial before the religious and civil powers of the world that 'the Spirit of [their] Father' will speak through them and give them the words they need to say $(10: 19-20)$. He reminds them of their infinite value in the sight of a God who cares even about the death of sparrows (10:29-31); and he affirms by comparison that nothing will happen to them 'apart from [their] Father' (10:29). In ultimate terms Jesus promises his disciples that if they 'endure to the end' they will be 'saved' (10:22//24:13).

Beyond the words of Jesus crucial events of Matthew's narrative confirm in powerful fashion the truth of which Jesus has spoken. In a pointed prolepsis at the beginning of Matthew's story God vindicates the life and the mission of the 'child who has been born king of the Jews' (2:2) by protecting the child from harm in the face of imminent and deadly threat from Herod the king $(2: 7-8,13,20)$. As that episode

67.In pronouncing a 'blessing' on his disciples ('Blessed are you ...': 5:11) Jesus also includes the 'prophets who were before you' $(5: 12)$ concludes, it is the 'child' who is alive and well in Nazareth (2:23), whilst Herod himself lies dead (2:19). In parallel scenes interpreting first Jesus' earthly ministry (3:13-17) and then, significantly, Jesus' suffering and death (17:1-8), the voice of God enters the story to acknowledge Jesus as 'my Son the Beloved' (13:17; 17:5), whilst the Spirit of God 'descends' on Jesus (3:16) and the power of God 'transfigures' Jesus with heavenly glory (17:2). At the moment of Jesus' death God unleashes the powers of the universe in a proleptic act of cosmic vindication, as he 'tears' the curtain of the Jewish temple in two, 'shakes' the earth, 'splits' the rocks, 'opens' the tombs of the departed faithful, and later 'raises' their bodies to life (27:51-53). And on the 'third day' (16:21; 17:23; 20:19; $27: 63,64)$ God takes final and definitive action to vindicate Jesus the 'Beloved Son' for the faithful and nonviolent life he has lived and the obedient death he has died. In an act of unparalleled power God overturns the death sentence of the Jewish council (26:66), condemns the mob actions of the Jewish crowd $(27: 22,23,25)$, and reverses the state-sponsored crucifixion of Jesus $(27: 26,35)$ as he raises Jesus from the dead $(27: 64 ; 28: 6,7)$, empties the tomb in which he was laid $(28: 1-$ $6)$, grants Jesus 'all authority in heaven and on earth' (28:18), and restores him to his followers $(28: 7,8-10,16-20)$ as the Risen Lord who will be 'with [them] always, to the end of the age' (28:20).

Here then is Matthew's ultimate word to his readers about the violence of the powerful and the suffering of the righteous. It is a paradoxical word that defies human reason and flies in the face of all human instinct. As the lived experiences of Jesus' own disciples within Matthew's narrative make clear, it is no easy word to receive. But for those prepared to receive it, Matthew makes clear that this word is nothing less than the transformative power of God at work in the human realm, obliterating the evident achievements of those who carry out violence and transforming the very real sufferings of the righteous into present 'blessing' and future resurrection.

\section{A few concluding reflections}

To read Matthew's story in the 21st century world is to experience the call to a discipleship breathtaking in its audacity and virtually inconceivable in its vulnerability. In this world of empire and military might, a world stockpiled with weapons of mass destruction, Jesus' disciples are called to renounce all use of violence and to 'put [their] sword back into its place' (26:52). In this world, where patriotic emotions are aroused daily by the public vilification of terrorists and the hideous violence that they unleash, Jesus disciples are called to lay aside hatred and revenge and to 'love [their] enemies' in imitation of their 'Father in heaven' (5:44). In this world where military violence is the 'knee-jerk' response of nation states to political conflicts of all sorts, Jesus' disciples are called to the dangerous and potentially deadly vocation of 'peacemaking' (5:9). In exchange for this inconceivable vulnerability Jesus' disciples are promised life lived through the resurrection power of God and in the ongoing presence of the Risen Jesus. It is the calling of a lifetime, fraught with challenge and pregnant with Good News. 


\section{References}

Muecke, D.C., 1969, The Compass of Irony, Methuen, London.

Weaver, D.J., 2003, “As sheep in the midst of wolves": Mission and peace in the gospel of Matthew', in M.H. Schertz \& I. Friesen (eds.), Beautiful upon the mountains: Biblical essays on mission, peace, and the reign of God, pp. 123-143, Herald Press, Scottdale, PA.

Weaver, D.J., 2001, 'The massacre of the innocents', in R. O'Grady, (ed.), Christ for all people: Celebrating a world of Christian art, p. 54, Orbis Books, Maryknoll, NY.

Weaver, D.J., 1990, Matthew's missionary discourse: A literary critical analysis, Sheffield Academic Press, Sheffield.
Weaver, D.J., 1996, 'Power and powerlessness: Matthew's use of irony in the portrayal of political leaders', in D.R. Bauer \& M.A. Powell (eds.), Treasures new and old: Recent contributions to Matthean studies, Symposium Series, no. 1, pp. 179-196, Scholars Press, Atlanta, GA.

Weaver, D.J., 2009, “"They did to him whatever they pleased": The exercise of political power within Matthew's narrative', HTS Teologiese Studies/Theological Studies 65(1), Art. \#319, 13 pages. doi: 10.4102/hts.v65i1.319

Weaver, D.J., 2005, “"Thus you will know them by their fruits": The Roman characters of the gospel of Matthew', in J. Riches \& D.C. Sim (eds.), The gospel of Matthew in its Roman imperial context, Journal for the Study of the New Testament suppl. 276, pp. 107-127, T \& T Clark, New York, NY.

Weaver, D.J. 1992, 'Transforming nonresistance: From lex talionis to "do not resist the

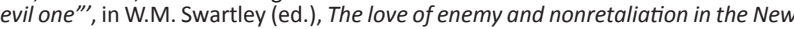
Testament, pp. 32-71, Westminster/John Knox, Louisville, KY. 